\title{
The phenomenon of bubu tradition in the cycle of time: Portrait of reciprocity in rural Madura
}

\section{Fenomena tradisi bubu dalam putaran zaman: Potret resiprositas di pedesaan Madura}

\author{
Halimatur Rizqiyah ${ }^{1 *}$, Warsono ${ }^{2}$, M. Jacky ${ }^{2}$, \& Nasution ${ }^{2}$ \\ ${ }^{1}$ Master Program of Social Studies Education, State University of Surabaya \\ ${ }^{2}$ Faculty of Law and Social Sciences, State University of Surabaya \\ Address: ${ }^{1,2}$ Jalan Lidah Wetan, Lakarsantri, Surabaya, East Java, Indonesia 60231 \\ E-mail: halimatur.19013@mhs.unesa.ac.id
}

Article History: Received 10 November 2020; Accepted 18 October 2021; Published Online 14 December 2021

\begin{abstract}
$B u b u$ is a form of reciprocity that occurs in Madura generally and Langkap Village particularly. Generally, the exchange is made by the community as a form of "donations" to the celebration host. The host hopes for a return in the future. The reciprocal incident that occurred in Madura was not just a hope but more of an "obligation" to pay the "donation" or bubu that had been given on the previous occasion. This study seeks to describe the form and meaning of the bubu as well as to explain the changes that occur in the bubu phenomenon which used to be only in the form of voluntary donations into various forms of bubu with their meanings. The research design used was an ethnographic study with a moderate method where the researcher was occasionally directly involved in the tradition. The results of this study reveal several forms of bubu that occur in Langkap Village with different ways and meanings with the same motivation. The $b u b u$ given is a transaction of accounts payable and investment with the hope of a return in the future. More than that, there are social sanctions that will await if the bubu that have been given are not returned with the same value.
\end{abstract}

Keywords: $b u b u$ tradition; investment; reciprocity; rural Madura; transaction

\begin{abstract}
Abstrak
Bubu merupakan bentuk resiprositas yang terjadi di daerah Madura pada umumnya dan di Desa Langkap pada khususnya. Umumnya, pertukaran yang dilakukan oleh masyarakat adalah berupa 'sumbangan' kepada pemilik hajatan dengan harapan adanya pengembalian di masa yang akan datang. Peristiwa timbal balik yang terjadi di Madura tidak hanya sekedar menjadi harapan namun lebih kepada 'kewajiban' untuk membayar 'sumbangan' atau bubu yang telah diberikan pada kesempatan sebelumnya. Penelitian ini berusaha mendeskripsikan bentuk dan makna bubu serta menjelaskan perubahan yang terjadi pada fenomena bubu yang dulunya hanya berupa sumbangan sukarela menjadi berbagai bentuk bubu beserta maknanya. Desain penelitian yang digunakan adalah studi etnografi dengan metode moderat di mana peneliti sesekali terlibat langsung dalam tradisi tersebut. Hasil dari penelitian ini mengungkapkan bahwa terdapat beberapa bentuk bubu yang terjadi di Desa Langkap dengan tata cara dan pemaknaan yang berbeda-beda namun dengan motivasi yang sama yakni bubu yang diberikan berfungsi sebagai transaksi utang piutang dan investasi dengan harapan ada pengembalian di masa mendatang. Lebih dari itu, terdapat sanksi sosial yang akan menanti apabila bubu yang pernah diberikan tidak dikembalikan dengan nilai yang sama.
\end{abstract}

Kata kunci: tradisi bubu; investasi; resiprositas; pedesaan Madura; transaksi

\section{Introduction}

In a wedding or party activity, the invitee or the host generally will receive a gift from the guests. The gift that is given to the bride and groom has a certain meaning (Rachmahani 2015). The meaning in it is both implicitly and explicitly to be "returned" with the same goods or with goods that have the same price as the ones that have been given. In this exchange, each individual receives and provides goods or services due to social obligations or certain motives (Hudayana 1991). The kind of this exchange is known as reciprocity. Reciprocity is a socio-economic exchange in which a person is obliged to give, 
receive, and return gifts in the same form or value. Mostly, reciprocity is carried out by close relatives who still have family ties, neighbors around the house who are in the same village, or other closest villages. Besides, reciprocity is also carried out among friends in formal or informal invitations. This implementation is an appreciation and participation of society in social life. The process of reciprocity is a form of social integration with four functions, including communication, social exchange, economic exchange, and socialization (Davies et al. 2010).

The reciprocity is performed not only in Indonesia, but throughout the world with various motivations. The exchange was first discovered by Bronislaw Malinowski in the early 19th century and almost the 20th called Kula in the Melanesia area, Papua New Guinea. Kula is an activity of giving gifts to a community that held a ceremony. The purpose of Kula is to respect one community by other communities. Both communities will do the same thing as an honor and a form of recognition in maintaining harmony between communities or tribes (Hann 2006). In this system, the goods that are exchanged are nonuse goods or have no selling value, but are very valuable for the Trobriand community as prestige to show the social status of each family and tribe. The right to participate in this kula exchange does not necessarily apply to every member of the community living in the archipelago, but only to certain people who have good social and political relations. A person should find his or her way to mobilize the abilities in social and political interactions. Therefore, the person will be able to join this exchange community. An important leader could have hundreds of kula while the ordinary society might only have no more than a dozen (Malinowski 1992).

Besides, in Pakistan, such exchange is commonly called naind or salaami as a gift in the form of a money necklace (sehra) given by families or friends in a wedding or birthday ceremony (Mughal 2018). Salaami is not only given in happy-themed ceremonies but also given when families experience difficulties or grief. It is called Ghami-khushi (sorrow and happiness). In Indonesia, the gift-giving tradition has been carried out in many major activities such as weddings or circumcisions, especially in rural communities or those who carry out donation activities. The naming of this tradition varies in each region, such as bubu (Madura) which comes from the words Buwuh (Javanese), Njagong (Central Java), Mbecek (Ponorogo/East Java), and others. Therefore, this activity has different terms. It is universal practically because almost every country has its own terms as studied by Mauss (1992) and Belshaw (1981) (in Lestari et al. 2012).

Moreover, "ancient" societies had an obligation to give, receive gifts, and then pay them (Mauss 1990), which is referred to as reciprocity, a well-known expression by an anthropologist who has long studied it in society. This proves that reciprocity has already been done by humans as the basis for social interaction. In some interactions, humans will always involve in the process of assessing behavior, including costs, rewards, and benefits. This is because humans are included in homo economics, an individual agent who is selfish, rational, and tries to get as much profit as possible (Hasan \& Azis 2018).

The rural society always upholding traditions as an obligation. Tradition seems to be their umbrella in making decisions and actions. Tradition is considered a factor that fulfills social functions. It forms structural logic and responds to society (Caille 1998 in Niederle \& Radomsky 2008). One example is $b u b u$ tradition which is practiced by the people of Langkap Village, Burneh District, Bangkalan Regency. The tradition of reciprocity has been passed down from generation to generation in marriage activities as an effort to establish the social integration of a society that is bound and harmonious (Beresnaviciute 2003).

In addition, the villagers build alliances as a form of their shared vision of mutual gifts or reciprocity (Heins et al. 2018). In the past, the $b u b u$ tradition was carried out when there was a wedding by providing labor and material contributions of agricultural materials such as rice, cassava, sweet potatoes, and corn as a form of support or participation in an event. During its development, the increase in economic demand changed the way the goods were exchanged in this bubu into money exchange. Over time, the tradition of donating this staple food has turned into an exchange of money, although bubu in the form 
of goods are still commonly found as accompaniment. Money has replaced bartering as a medium of exchange due to the complexity of human needs (Sari 2016). All needs can only be resolved with money and people need the money more than just given things. The pressure of monetization has changed the socio-cultural life in society (Utami 2015).

The expression "Money is not everything, but everything needs money" seems to apply to the life of rural communities as well. In terms of reciprocity, rural communities have also experienced changes. The exchange of goods and services has been linked to the exchange of money (Meera \& Kumar 2015). Women are the actors behind this change (Lestari et al. 2012) given that women directly interacted with this reciprocity occasion. Women are the core part of a family, financial holders, and frequently decision-makers in matters of household expenses (Widhyharto 2015). Women are directly involved with reciprocity because, in every event, they take on many important roles, including giving and receiving bubu.

Other than that, the economic factors are considered to be one of the reasons for changes in reciprocity (Bakhri 2018). People tend to give reciprocity based on generosity and sincerity in positive reciprocity, however negative reciprocity results in social punishment if it does not have equal value. Negative reciprocity is considered to be fairer in implementing reciprocity than positive reciprocity (Shaw et al. 2019). It means that a reciprocal event in an exchange would be better if returned with the same goods, the same specifications, and in the same condition. The bubu tradition in Langkap Village shows that the reciprocal process carried out must be based on the intention to return the goods according to existing specifications. It shows that there is a change in the solidarity of society from the past to the present where it is more concerned with the same form of return than the desire to help another. Negative reciprocity has infiltrated the bubu activity because it has been affected by the economic and market system. Therefore, pure solidarity in society is falling behind (Antropedia 2018).

There are some previous studies related to reciprocity such as social actors contributing to reciprocity (Lestari 2014), motivation to make donations (Miller et al. 2017), portrait of reciprocity (Lestari et al. 2012), and the principle of reciprocity in the banking world (Rahadiyan 2019). Meanwhile, this study presents the phenomena that occur in the culture of reciprocity of the Madurese community, especially Langkap Village, Burneh District, Bangkalan Regency.

This study seeks to describe the form and meaning of the bubu tradition as well as to explain the changes that occur in the bubu phenomenon which used to be only in the form of voluntary donations into various forms of $b u b u$ with their meanings. It also studies how the people of Madura respond to various forms of $b u b u$ in the midst of their limitations. This reciprocity provides an understanding that this is a social phenomenon that is currently happening. This at the same time breaks the notion that "life in the village is easier" because life in the village places more emphasis on the high social spirit of society than understanding the economic conditions of each individual.

\section{Research Method}

This study used a qualitative method in which the researcher digs in-depth information as the data source. The qualitative method is used to obtain information through in-depth interviews, observations, and document extraction (Wahidmurni 2017). The research design used was ethnography, which focuses on cultural aspects inherent in the social system (Kamarusdiana 2019). According to Spradley (1980) in Koeswinarno (2015), the most important part of ethnographic research is participant observation, where the researcher is directly involved in the routine of research subjects, observes what is done, and listens to what is said. In addition, Spardley divides the observation model into four parts, including complete, active, moderate, passive, and non-participation (Koeswinarno 2015).

In addition, several characteristics can describe ethnographic research including cultural themes, groups of various cultures, shared behavior patterns, beliefs and languages, field research, information 
or settings, and researchers' reflections (Creswell 2012). Data collection techniques used observation, interview, and documentation. Data analysis used in this method was conducting interviews with three steps. The first was interviewing the celebration hosts and guests in different places and times. The second was analyzing the interview data. The third was interpretive analysis which allows for new themes outside of cultural identity (Burke et al. 2018).

Further, the researcher observed the involvement in a moderate way, where the researcher would occasionally be involved in the procession of the event and become part of the recipient of guests, the recipient of bubuwan (bubu money), and the guests themselves. The object of research was carried out in Langkap Village, Burneh District, Bangkalan Regency from June 2019 to June 2020. The informants were actors who were directly involved in reciprocal activities, such as guests, bubuwan registrar, and event hosts. There were ten informants, nine of them were women and one of them was a man who act as a local religious leader. The reasons for choosing these informants are that they were directly involved in this reciprocity activity and on average, the informants were people with economic problems who have difficulty returning the $b u b u$.

\section{Results and Discussion}

Langkap Village is located not too far from the urban center in Bangkalan. However, the growth of the mindset of the people in this village is still quite difficult to accept change. The low level of education also drives this happening. As in the reciprocal practice that occurs in this village community, most people think that a wedding activity is a way to withdraw the money that has been invested (for the event hosts) and a way to hand over debts (for the invitees).

\section{Bubu in wedding party}

Marriage is a sacred event in religious communities, including Islam as the religion of the majority of the Madurese. This event is the day that the bride and groom have been waiting for. However, it becomes complicated for the couple's parents because they have to hold a celebration and it requires a lot of money. In a wedding ceremony, generally, invitations will be distributed to relatives, friends, and colleagues to enliven the event. Besides, it serves as proof to the public that there has been a marriage ceremony.

In Langkap Village, the distribution of invitations is divided into several levels: 1) the invitation from the father of the bride is addressed to the father, 2) the invitation from the mother of the bride is addressed to the mother, 3 ) the invitation from the bride is addressed to female colleagues. If the groom is also a neighbor or person known by the invitation, in the sense that the bride and groom are people who are equally known by the recipient of the invitation card, the level increases, 4) invitation from the father of the groom to the father in the invited family, 5) invitation from the mother of the groom to the mother in the invited family, and 6) invitation from the groom is intended for male party colleagues. Sometimes a person will receive at least 6 invitations addressed to each family member. The invitation can be increased if a family has several teenagers who are the same age as the bride and groom or at least the teenager has entered puberty or around junior high school.

"I have 6 children. If it's the season of the wedding, we receive lots of invitations both from the groom's family as well as from the bride. Because I have teenagers who are in junior high, high school, and university levels, it is common for us to receive 10 invitations from both men and women at one time and one wedding ceremony." (interview, YEN, 40 years).

Each recipient of an invitation is obliged to give a bubuwan or make a contribution in three categories: the first is voluntarily for those who have never received a bubuwan (never held a celebration before). The second is obligatory for those who have received a bubuwan (have held a celebration). Third, women are obliged to bring ban-giban (luggage) or accompanying bubu in the form of staple food ingredients such as rice, sugar, cooking oil, or noodles (not instant noodles). 
“... One time we had to spend money of IDR 50,000, - bubu for my husband, IDR 50,000, - bubu for me, and IDR 20,000 each for my 3 children which were addressed to the groom's event. We also pay the same money for the bride's event. So in total, that day we spent IDR 320,000 for one event, plus $2 \mathrm{~kg}$ of rice and $1 \mathrm{~kg}$ of sugar as assistance to the event host." (Interview, YEN, 40 years).

“...time to pay the debt. In the past, I held a celebration for my 4th child. One guest paid IDR 20,000 per male (father) and IDR 15,000 per female (child) and $2 \mathrm{~kg}$ of rice and 1 liter of certain brands of cooking oil. Let my son who was invited to pay for himself. He's already married." (Interview, MAI, 56 years).

The host of the wedding will provide many things to prepare for the event. In addition to the neatly arranged decorations to welcome the bride/groom, the hosts also prepared a place with beautiful decorations consists of a small table, filled with several neatly arranged snacks. Other than that, there are seven different types of flowers with incense as a medium. It was used as a mystical lure to attract the guests to come. The hope is that all the guests come to hand over bubuwan. The host will feel overjoyed if many guests come. Apart from feeling proud because the event attracted the attention of the residents, the host also received many bubuwan from the guests.

“... The fruits are placed as a complement so that this small table looks full, while the flowers and incense are used to attract the guests to make all family members come (complete). The host will feel embarrassed if the number of guests is not as expected. Besides being embarrassed, they will also feel a loss." (interview, KUS, 30 years old).

Then, there is a woman behind the table who is in charge of taking note of the bubu. All guests will automatically go to this note-taking woman to write the bubuwan. Besides, several women also write the goods that were brought by the female guests. This woman sits not far from the bubuwan registrar and is equipped with a scale to weigh the belongings of female guests who will also hand over the bangiban. This receptionist will weigh the goods such as sugar, rice, oil, noodles, sugar along with the brand in the package. Therefore, the host will be able to pay the debt according to what has been recorded in the bubuwan book. Most of the roles in the event are dominated by women. This proves that the role of women is not only limited to as a mother or actor in the household but also as social beings who are always involved in the public sector (Shonhaji 2017). Women are individuals who cannot stand without their world, without communication and participation in their life (Kartono 1992).

In several situations, the researcher found guests with different specifications. First, upper-middle-class/ educated guests are usually reluctant to face the bubuwan registrar. The bubuwan money is immediately handed over to the host while the ban-giban will be taken by the ban-giban registrar. Usually, these guests do not intend to pay debts but only want to ease the burden on the host.

“...Teacher, religious leader (Kiai), or wealthy people will immediately come to me. The envelope that already had a name was handed directly to me. I'll hand it over to the note taker." (Interview, LAI, 42 years old).

“...the bubu given by the teacher was IDR 50,000. She doesn't have any married children, so she gave bubu the best she can. Meanwhile, Umik (female religious leader) was a rich woman. I remember that I spent IDR 20,000 at her son's wedding, but she gave me IDR 100,000. It means that later when her 3rd child gets married, I will have to pay IDR 100,000 if I have. Usually, if Umik doesn't mind the amount, I must give the same as what has been given." (interview, MUS, 42 years).

Second, there is a type of guest who comes specifically to pay off debts. These guests do not dress up formally. They dress in the same way they do at home. These guests will immediately come and approach the bubuwan note taker. Then, they pay the debt from the previous celebration where the host 
had given the same amount. After that, the guests will make a new contract by giving bubuwan outside the debt record. It means that the guest makes a record of accounts receivable that will be returned by the host.

“... Usually when they work as a farmer, they don't have time to groom. They just come, pay bubuwan, get snacks, and go home. The money does not need to be wrapped in an envelope, but it is immediately handed over to the note taker, and it will be recorded later. If you ever have a bubuwan debt, the guest will pay according to the bubuwan money you have received. If the debt used to be IDR 15,000 and 1 kilo of sugar, the guest will pay the same amount. Then, the guest will leave the event." (interview, MUS, 42 years old).

Third, there is a type of guest who has the relation as the host' family. The guests would come in the previous day and bring lots of groceries to donate. This form of donation is not voluntary or shodaqoh, but is more of an investment to the host. The purpose is to get the same amount of donation as that has been previously invested from the host when the guests held a wedding party.

“... if my distant family donate $50 \mathrm{~kg}$ of rice, $10 \mathrm{~kg}$ of sugar, 10 liter of oil, and $10 \mathrm{~kg}$ of eggs, later when their child gets married, I have to be able to donate the exact same as given now." (interview, SIT, 45 years).

"It's still better to be given only $50 \mathrm{~kg}$ of rice, $10 \mathrm{~kg}$ of sugar, or oil. Some of them really intend to bring 3 sacks of rice and some others donate cows ...." (interview, MAI, 56 years old).

In conclusion, these investments have a purpose. The first is they want to ease the burden of relatives or friends who are experiencing difficulties in holding a wedding. This is because the wedding requires a large amount of money. The second is they want to show their social status owned by the 'investors' to the host (Mohlis 2019). Therefore, Langkap society built a form of reciprocity that was not based on trust (altruism). This is because the basis of mutual commitment is to return more money or goods that had been given than the number of bubuwan. They also expect that they will get a bigger amount of money and goods from guests who come to join in celebrating. "...It's okay if the person doesn't come, the important thing is that the donation is deposited or given..." (interview, NAN, 48 years old).

\section{Bubu in circumcision}

$B u b u$ in circumcision is not much different from bubu in weddings. In this activity, the recipient is obliged to hand over his/her "debt" when his/her son is also circumcised. However, when all children have been circumcised, the obligation to return the bubu is done when the child is about to get married. As is known in Islamic theory, boys are obliged to perform circumcision or cut the outer skin of the penis which serves to prevent the dirt from accumulating in the foreskin which will make it difficult for men who are already baligh to prayers legally. There is no limitation of age in carrying out circumcision, but based on the Madurese culture, it is held when the child is born to the age when they are in elementary school on $6^{\text {th }}$ grade.

The invitation system that is carried out at circumcision events is a small celebration that only invites relatives and neighbors. Further, this does not rule out the possibility of event hosts distributing invitations like weddings. However, only parents who invite because there are no partners of people who are circumcised like in a marriage. Usually, this serves two purposes. The first is to open the bubuwan to attract guests so that they can receive lots of bubuwan. The second is to get bubuwan from people who have invited the hosts but have no plans to hold a marriage ceremony soon. It is as stated by the following informant "...o son, if you held a big circumcision event, you will get a lot of donations ... later the money can be used to pay debts" (Interview, FAI, 43 years old). This was also conveyed by another informant. 
“... if I don't hold a big celebration, unfortunately, I will not get back the donations I have given to the people who have invited me. If all people are invited, my money will be back soon because my child is still getting married" (Interview, TIN, 30 years old)

The concept remains the same as the wedding ceremony where bubuwan will be recorded in accordance to the nominal of money given to the circumcised child, or to the parents who are responsible for the event.

\section{Collecting bubu to collect debts in the tok-otok and saweran tradition}

The term tok-otok comes from the word tok-kotok which literally means whisper. This term was originally used to collect donations from neighbors when a tok-otok actor had a big financial problem, either is used to pay debts or treat a family member who is sick and requires a lot of money. Another reason that can be used is that those who have the intention of tok-otok no longer have children to get marry or circumcise, but the bubu has been scattered in many invitations. Therefore, they feel the need to hold an event for returning the bubu that has been scattered.

Inviters do not need to bother printing invitations for this event. This is because the exact meaning of tok-otok is a whisper, so the way to invite them is directly to talk to the guest. This behavior has happened in ancient times. In asking for donations, the Madurese were different in the way they were invited (Rochana 2012). This tok-otok has now made its official invitation, which is shorter than the wedding invitation. The shape resembles a name card with the words "Selametan Keluarga" or "Family Celebration" written on it.

This culture has its own community and the invitation is spread only to their community. The concept is almost the same as arisan or regular social gathering. There is a turn about the person who will hold the event and who will be the donor. There is a difference between arisan and tok-otok. The arisan has a fixed fee in each payment, but tok-otok does not specify the amount of money that should be paid. If anyone intends to invest or save, then they can give the amount as much as bubuwan. However, if the bubuwan is only limited to paying the debt, the amount of bubuwan is equal to the money that was received at the previous wedding/circumcision/tok-otok event.

The main reason for inviters who hold tok-otok because they do not have children who are going to get married or circumcised is purely intended for refunds that have been spread in many parties.

“...There are a lot of donations that have been distributed. My children are all married. Lots of donations are still in the hands of people. It is more practical to pray for this tok-otok so that the money that's still lodged in people can be retrieved as soon as possible. ..." (Interview, NUR, 62 years old).

Meanwhile, according to Kamus Besar Bahasa Indonesia (KBBI), the word sawer means asking money from the audience to be given to the performer (KBBIonline 2020). The word and the culture of saweran originate from the Sundanese region, but it has been used in various areas in Indonesia such as Madura. There are differences in the way the sawer is used in its two areas. In the origin area, sawer is done by people who have a lot of money voluntarily and then distributed to the performers. However, sawer in Madura was given to performers by families or close friends who had a celebration. They give money and deliberately is documented via video. The goal is that the video will be used as evidence for the next time if the viewer holds the same event, then the sawer giver has the right to collect back the money that has been given to the performers.

“...This is a new culture that once did not exist in this village. Only classy people usually use saweran. But it seems that now this culture has also begun to be used by ordinary people. That means they have a lot of money..." (Interview, MAI, 46 years old). 


\begin{abstract}
"Nowadays there are videos (from smartphones), so there is no need to always record them, especially if it is difficult to record this saweran. The money that is sown is a lot, even if the value is small. So, recording it in a form of video is better because it's more accurate." (Interview, LAI, 42 years old).
\end{abstract}

The form and variety of reciprocity gradually change along with the development of civilization and times that have changed. This is inseparable from changes in the lifestyle and socio-economics of rural communities. Human needs are many and varied, increasing continuously in line with the development of civilization and technological progress (Gunawijaya 2017). As a result of changing times, people's motivations shift from giving donations to other ways of giving. It is in line with what has been stated by Emile Durkheim regarding social solidarity that social solidarity has two parts, including mechanical solidarity and organic solidarity (Wulandari \& Irwansyah 2020). Mechanical solidarity places more emphasis on a shared collective consciousness that rests on shared beliefs and sentiments. In Durkheim's description, mechanical solidarity is more about emotional attachment in a group so that a strong sense of shared destiny is felt. However, individuals in this group can change as a result of being constantly under pressure in the face of the times. Human collective consciousness is not stagnant and constantly changing. The growing necessities of life and the increasing division of labor make this change inevitable. Then, organic solidarity arises as a result of the decline in collective consciousness (Setiawan 2013). This change in solidarity has brought about a change in the motives for the tradition of donating in the present, as happened in Langkap Village, Burneh District, Bangkalan Regency, that has been split into various forms and varieties of $a b u b u$. A religious figure who during his life served the community in Langkap Village stated:

"... in Islam, there is a saying of the prophet which reads "tahaduu tahabbu" which means give each other gifts, then you will love each other. From this hadith, it can be interpreted that in the relationships among neighbors and relatives, it is good to give each other donations. There will be harmony between neighbors and relatives. Unfortunately, as time goes by, this mutual contribution activity is then used as a new motive where everything must be taken into account, one does not want to be harmed. So, there are many forms of donating and it is now developed as bubu..." (Interview, FAT, 50 years old).

From the interview excerpt above, it can be concluded that the changing times have triggered a change in form and motivation in donating. This change can be triggered by socioeconomic factors and the times.

\title{
Conclusion
}

The form of reciprocity found in Langkap Village, Burneh District, Bangkalan Madura, is very different from the concept of reciprocity in general. While the concept of reciprocity is actually to strengthen social relations, in practice the bubu tradition is like a heavy burden that must be borne because they are accepted as debts and receivables. There is no pride, authority, or blessing that is tucked away in the reciprocity presented in this tradition but only a social obligation to maintain their existence or good name.

The theory put forward by Emile Durkheim regarding the change of mechanical solidarity into organic solidarity has actually happened to the people of Langkap Village, Burneh District, Bangkalan Regency. One of the triggers for this change is socio-economic factors and the development of the times so that changes in motivation in donating are inevitable. This study concludes there are several forms of contribution but with the same motive, namely accounts payable. The bubu given is a transaction of accounts payable and investment with the hope of a return in the future. More than that, there are social sanctions that will await if the bubu that have been given are not returned with the same value. 


\section{References}

Antropedia (2018) Antropologi ekonomi (resiprositas). Antropedia Kawan Undip. 01 August [Accessed 21 April 2020]. https://antropediakawanundip.wordpress.com/2018/08/01/antropologi-ekonomiresiprositas/.

Bakhri S (2018) Resiprositas dalam sunat poci dan mantu poci masyarakat Tegal. Jurnal Analisa Sosiologi 7 (1):94-109.

Belshaw CS (1981) Tukar Menukar Tradisional dan Pasar Modern. Jakarta: PT Gramedia.

Beresnaviciute V (2003) Dimension of social integration: Appraisal of theoritical approach. Etnicity Studies Journal 96-108.

Burke M, Hooper D, Khusida B, Lyon P, Mynard J, Sampson R, \& Taw P (2018) Observing a social learning space: A summary of an ethnographic project in progress. Relay Journal 1 (1):209-220.

Creswell JW (2012) Research Design Pendekatan Metode Kualitatif, Kuantitatif, dan Campuran. Yogyakarta: Pustaka Pelajar.

Davies G, Whelan S, Foley A, \& Walsh MM (2010) Gifts and gifting. International Journal of Management Reviews 12 (4):413-434. https://doi.org/10.1111/j.1468-2370.2009.00271.x.

Gunawijaya R (2017) Kebutuhan manusia dalam pandangan ekonomi kapitalis dan ekonomi Islam. AlMaslahah 13 (1):131-150.

Hann C (2006) The gift and reciprocity: Perspectives from economic antropology. In: Kolm S \& Ythier JM (eds). Handbook on the Economics of Giving, Reciprocity, and Altruism 1 (4):207-223.

Hasan M \& Azis M (2018) Pembangunan Ekonomi dan Pemberdayaan Masyarakat: Strategi Pembangunan Manusia dalam Perspektif Ekonomi Lokal. Makassar: CV Nur Lina \& Pustaka Taman Ilmu.

Heins VM, Unrau C, \& Avram K (2018) Gift-giving and reciprocity in global society: Introducing Marcel Mauss in International studies. Journal of International Political Theory 14 (2):126-144. https://doi.org/10.1177/1755088218757807.

Hudayana B (1991) Konsep resiprositas dalam antropologi ekonomi. Jurnal Humaniora 3:20-34.

Kamarusdiana (2019) Studi etnografi dalam kerangka masyarakat dan budaya (community and culture framework in etnographic studies). Jurnal Sosial dan Budaya Syar-i 6 (2):113-128. https://doi. org/10.15408/sjsbs.v6i2.10975.

Kartono K (1992) Psikologi Wanita: Mengenal Manita sebagai Ibu dan Nenek. Bandung: CV Mandar Maju.

KBBIonline (2020) Kamus Besar Bahasa Indonesia Online 2012-2019 Versi 2.8. Hak Cipta Pusat Pengembangan dan Pembinaan Bahasa (Pusat Bahasa). [Accessed 05 October 2020]. https://kbbi. web.id/sawer.

Koeswinarno (2015) Memahami etnografi ala Spradley. Jurnal SMaRT 1 (2):257-265.

Lestari S (2014) The tradition to donate among woman in Javanese rural areas: Reciprocity, food exchange and monetization. Journal International of Sociology and Anthropology 6 (7):205-213.

Lestari S, Sumarti T, Pandjaitan NK, \& Tjondronegoro SMP (2012) Potret resiprositas dalam "tradisi nyumbang" di pedesaan Jawa di tengah monetasi desa. Masyarakat, Kebudayaan dan Politik 25 (4):271-281

Malinowski B (1922) Argonauts of the Western Pacific: An Account of Native Enterprise and Adventure in the Archipelagos of Melanesian New Guinea. London: Routledge \& Kegan Paul.

Mauss M (1990) The Gitf; Forms and Functions of Exchange in Archaic Societies. London: Routledge.

Mauss M (1992) Pemberian: Bentuk dan Fungsi Pertukaran di Masyarakat Kuno (Terjemahan). Jakarta: Yayasan Obor Indonesia.

Meera S \& Kumar DC (2015) Reciprocity, exchange, and social solidarity. International Research Journal and Social Science 4 (5):84-88.

Miller JG, Goyal N, \& Wice M (2017) A cultural psychology of agency: Morality, motivation, and reciprocity. Association for Psychological Science 12 (5):867-875.

Mohlis (2019) Tradisi "Bubuh"; membalas amplop nikahan di Madura. Mata Madura: Media Pencerah Mengedepankan Solusi. [Accessed 06 October 2020]. https://matamaduranews.com/tradisibubuh-membalas-amplop-nikahan-di-madura/. 
Mughal MAZ (2018) Exchange relationship and social change in rural Pakistan: Rituals and ceremonies of childbirth, marriage and death. South Asia Research 38 (2):177-194. https://doi. org/10.1177/0262728018768137.

Niederle A \& Radomsky GFW (2008) Social actors, markets and reciprocity: Convergences between the new economic sociology and the "paradigm of the gift". Teoria \& Sociedade 15 (1):146-177.

Rachmahani H (2015) Gift-giving behavior pada generasi millennials di Indonesia, perspektif pembawa hadiah. Thesis, Universitas Airlangga, Surabaya.

Rahadiyan I (2019) Pemaknaan dan penerapan prinsip resiprositas berdasarkan ASEAN Banking Integration Framework. IUS Quia Iustum Law Journal of Islamic University of Indonesia 26 (3): 545-564.

Rochana T (2012) Orang Madura, suatu tinjauan antropologis. Jurnal Humanus 11 (1):46-51. https://doi. org/10.24036/jh.v11i1.622.

Sari SW (2016) Perkembangan pemikiran uang dari masa ke masa. Jurnal An-Nisbah 3 (1):39-58. https://doi.org/10.21274/an.2016.3.1.39-58.

Setiawan R (2013) Solidaritas mekanik ke solidaritas organik (suatu ulasan singkat pemikiran Emile Durkheim). Universitas Maritim Raja Ali Haji 259-266.

Shaw A, Barakzai A, \& Keysar B (2019) When and why people evaluate negative reciprocity as more fair than positive reciprocity. Cognitive Science A Multidicipline Journal 43 (8):1-35. https://doi. org/10.1111/cogs. 12773.

Shonhaji (2017) Keterlibatan perempuan dalam mewujudkan keserasian sosial pada masyarakat multiteknik di Lampung. Jurnal TAPIs 14 (1):17-44. https://dx.doi.org/10.24042/tps.v13i1.1397.

Utami IWP (2015) Monetasi dan perubahan sosial ekonomi masyarakat Jawa abad XIX. Jurnal Sejarah dan Budaya 9 (1):51-63.

Wahidmurni (2017) Pemaparan metode penelitian kualitatif. Metodologi Penelitian, Jurusan Pendidikan Ilmu Pengetahuan Sosial Fakultas Ilmu Tarbiyah dan Keguruan, Semester Ganjil 2017/2018. (Unpublished) [Accessed 27 December 2020]. http://repository.uin-malang.ac.id/1984/2/1984. pdf.

Widhyharto DS (2015) Perempuan sebagai agen sosial-ekonomi masyarakat pesisir sekitar PLTH (Pembangkit Listrik Tenaga Hybrid) Pantai Baru, Kabupaten Bantul, Daerah Istimewa Yogyakarta. Indonesian Journal of Community Engagement 1 (1):156-171.

Wulandari P \& Irwansyah I (2020) Warga Madura di Kota Makassar: Studi antara solidaritas sosial mekanik dan solidaritas sosial organik warga Madura dalam wadah PERKIM Kota Makassar. Jurnal Predestination: Journal of Society and Culture 1 (1):9-14. https://doi.org/10.26858/prd. v1i1.14984. 